\title{
ТЕОРЕТИЧНИЙ АСПЕКТ ЗАРОДЖЕННЯ Й РОЗВИТКУ ПОЛІКУЛЬТУРНОГО ВИХОВАННЯ
}

\author{
Вертегел В. Л., Хребтова В. В.
}

\section{ВСТУП}

Серед великого розмаїття концепцій виховання на сучасному зрізі розвитку науки в контексті загальної гуманізації та демократизації суспільства особливого значення в соціумі набуває роль творчої особистості. Оскільки саме творчо обдарована людина $з$ притаманною для неї жагою до самопізнання, саморозвитку і самовдосконалення, а також із властивим для неї високим рівнем духовності та загальної культури може бути взірцем нових морально-етичних норм та цінностей сучасного світу. Лише така цілісна особистість може володіти гуманістичним світоглядом та бути відкритою до інших культур і водночас володіти знаннями своєї культури. Останнім часом відбуваються інтенсивні інтеграційні процеси як у нашій країні, так і в цілому світі, які впроваджуються майже в усі сфери людського життя: науку, культуру, політику, економіку тощо. Тому на перший план виходять уміння спілкуватися та взаємодіяти 3 представниками різних культур. Разом із пізнанням чужої культури ми можемо проаналізувати й систему власної. Зважаючи на це, особливого значення набуває полікультурна освіта. Не випадково одним із пріоритетних завдань Національної доктрини розвитку освіти в Україні у XXI столітті $\epsilon$ формування школи полікультурного виховання, в центрі уваги якої перебуває саме культуротворчий складник і його вплив на формування творчої особистості та всебічне розкриття іії здібностей. На сучасному етапі розвитку світової цивілізації та глобалізації всіх іiі процесів виникла потреба в стратегічному підході до виховання полікультурної особистості, яка повинна володіти іноземними мовами, поважати культуру та звичаї інших народів.

Полілінгвістична освіта відкриває нові горизонти для розвитку особистості й спрямована на розширення культурних зв'язків між країнами. Особливого значення в ній набуває розширення знань про культуру, мистецтво та традиції різних народів світу, оскільки в подальшому вони сприятимуть зміцненню взаєморозуміння між країнами та культурному взаємозбагаченню. Саме зараз світовою спільнотою розробляється нова освітня стратегія полікультурної освіти, мета якої полягає в підготовці майбутнього молодого покоління до життя й ефективної діяльності в умовах поліетнічного 
й полікультурного середовища, а також до толерантних взаємин між націями й народами як усередині держав, так і на міжнародному рівні.

\section{1. Історія виникнення полікультурного виховання}

Ідея полікультурності в освіті існувала задовго до сьогодення. На згадку про неї ми натрапляємо в працях видатних учених, педагогів та діячів культури минулих років. Найбільший внесок у розвиток цього явища зробив відомий чеський педагог XVI ст. Я.А. Коменський у своїй програмі «Пампедія». У центрі ії уваги перебуває принципове визнання спільності людей, їх потреб, прагнень та переконань, оскільки це програма універсального виховання всього людства, яка не залишається поза увагою навіть сьогодні. Я.А. Коменський у своїй роботі виклав прості, але фундаментальні речі, наголошуючи, що потрібно всіляко сприяти формуванню в молодшого покоління вміння жити в злагоді $з$ іншими, виконувати взаємні обов'язки, поважати та любити людей ${ }^{1}$.

Одним із провісників сучасної полікультурної освіти був видатний педагог і психолог П. Каптєрєв. Його ідеї привнесли багато цікавого і нового в поняття «полікультурна освіта». Иого погляди на розуміння значення полікультурної освіти у формуванні особистості так само мають безперечну цінність. Він першим запропонував ідею єдності національного й загальнолюдського в педагогіці та наголошував на тому, що полікультурна освіта має бути невід'ємним складником професійної діяльності вчителів ${ }^{2}$. П. Каптєрєв уважав, що в дитини необхідно розвивати почуття приналежності до всього людства, оскільки діти не повинні вважати, що «рідний народ є єдиним носієм справжньої культури, а інші народи мають служити йому»³. До національних цінностей П. Каптєрєв зараховував мову й релігію. У його розумінні розвиток національних цінностей полягав у вивченні рідної мови. Але водночас вивчення рідної мови розглядалося ним як залучення до загальнолюдських цінностей. Отже, П. Каптєрєв підтримував ідею розвитку національної самосвідомості й загальнолюдського в учнях. Він схилявся до думки, що на початку педагогічної діяльності слід віддавати перевагу національним ідеалам, а вже потім загальнолюдським: у вихованні слід звертатися не до «одного народу, а до багатьох, розглядати їхні ідеали й доповнювати те, чого не вистачає своєму національному ідеалу, цінними властивостями інших народів,

${ }^{1}$ Коменский Я.А. Избранные педагогические сочинения: В 2 т. Т. 2 Москва : Педагогика, 1982. 395 с.

2 Хребтова В.В. Зародження й перспективи розвитку полікультурного виховання. Вісник Запорізького начіонального університету. 2007. № 2. С. 229-233.

${ }^{3}$ Каптерев П.Ф. Избранные педагогические сочинения. Москва, 1982. С. 307. 
народне треба поєднувати 3 іноземним, 3 усенародним і загальнолюдським» ${ }^{4}$.

Вагомий внесок у розуміння сутності полікультурної освіти зробили також відомі вчені початку ХХ ст. М. Бахтін і Л. Виготський. Філософ, культуролог, літературознавець та теоретик європейської культури М. Бахтін розглядає культуру як діалог, в якому людина є унікальним світом культури. М. Бахтін у своїх роботах розмірковує про людину як про особистість, яка розвивається в процесі взаємодії 3 іншими особистостями й одночасно впливає на них. Він широко розкриває у своїй роботі ідею діалогу культур не лише як форми спілкування людей, але й як способу взаємодії людей із культурою різних часів.

Не менш вагоме значення для обгрунтування поняття полікультурної освіти має культурно-історична теорія розвитку поведінки й психіки видатного психолога Л. Виготського, в основу якої покладено думку про те, що є безпосередній зв'язок між психікою та історичним розвитком культури певного народу. Автор обстоює думку, що полікультурне виховання не $\epsilon$ спадковим, воно не передається генетично, а формується в певному культурному середовищі. Спочатку культурний розвиток людини спостерігається в соціальному середовищі, а потім уже закріплюється в психологічному плані. Учений переконаний, що положення щодо провідної ролі соціокультурного контексту в розвитку людини передбачає врахування в становленні особистості конкретних реалій, визначає значущість у формуванні свідомості учня навколишнього середовища, відносин із людьми, ставлення до тих чи інших культурних цінностей ${ }^{5}$.

Автори міжнародного педагогічного словника намагалися першими дати визначення поняттю «полікультурна освіта». Термін "multicultural education” вони пояснювали як відображення ідеалів культурного плюралізму у сфері освіти. На визначення поняття "multicultural education" натрапляємо в Міжнародній енциклопедії освіти, де воно трактується як «педагогічний процес, у якому репрезентуються дві (або більше) культури, що відрізняються за мовною, етнічною, національною або расовою ознакою» ${ }^{6}$. Проте існують й інші думки щодо того, де вперше з'явився термін «полікультурна освіта».

Серед американських педагогів найширше це питання розглядається в зарубіжних концепціях мультикультурної освіти Дж. Бенкса. В основу розробленої ним концепції полікультурної освіти покладено розуміння культури й тієї ролі, яку етнічна приналежність відіграє

${ }^{4}$ Каптерев П.Ф. Избранные педагогические сочинения. Москва, 1982. С. 56.

5 Выготский Л.С. Избранные психологические исследования. Москва, 1956. $520 \mathrm{c}$.

${ }^{6}$ International Dictionary of Education by G. Terry Page \& J. B. Thomas ; with A. R. Marshall. The MIT Press, 1980. 224 p. 
в американському суспільстві. Оскільки це суспільство складається з багатьох етнічних підсуспільств, які $\epsilon$ носіями унікальних культурних характеристик, що не стали всезагальним надбанням, полікультурна освіта відіграє важливу роль у соціалізації багатьох американців і допомагає їм задовольняти важливі життєві потреби. Так, одним iз вимірів полікультурного виховання Дж. Бенкса $\epsilon$ «педагогіка справедливості» ${ }^{7}$, під якою він розуміє використання вчителями у своїй роботі методів та прийомів, котрі сприяють покращенню академічної успішності учнів різного етнічного, расового та соціального походження. Він особливо наголошує на забезпеченні рівних освітніх можливостей представникам усіх етнічних, расових, культурних, мовних, релігійних гендерних та соціальних груп.

Вивчення розробок у галузі мультикультурної освіти в США є доцільним, зважаючи на великий досвід цієї країни у вирішенні конфронтацій різних расових й етнічних груп. Еволюція теорії міжкультурного спілкування продемонструвала надзвичайну комплексність феномену людського спілкування взагалі та значні відмінності в стандартах, цінностях i навіть моделях мислення і поведінки, властивих представникам різних культур. Існування культурних відмінностей, властивих полікультурним суспільствам, не могло не відобразитися на системі освіти. Американській полікультурній освіті властивий плюралізм культур в освіті. Ідеться про визнання розходження в культурі як факту життя американського суспільства, підтверджуючи, що культурна багатоманітність є цінним ресурсом, який варто зберігати й примножувати ${ }^{8}$.

Аналіз сучасної літератури показує, що міжкультурна взаємодія в педагогічному процесі позначається низкою синонімічних термінів. Серед них найбільш уживаними є такі: «поліетнічна освіта», «кроскультурна освіта», «міжкультурна освіта», «інтеркультурна освіта», «мультикультурна освіта». У документах Ради Європи з питань освіти і культури використовуються терміни "multiethnic" «мультиетнічний», “culturally diverse" - «культурно різноманітний» та "education for diversities" - «освіта задля збереження культурної різноманітності» ${ }^{9,10}$.

7 Banks J.A. Multicultural Education: Characteristics and Goals. Multicultural Education: Issues and Perspectives. 7th edition. John Wiley and Sons, 2010. P. 3-30.

${ }^{8}$ Hunter William A. Multicultural Education Through Competency-Based Teacher Education. Washington, D.C. : American Association for Colleges of Teacher Education, 1974. P. 21.

${ }^{9}$ Faas D., Hajisoteriou C., Angelides P. Intercultural education in Europe: Policies, practices and trends. British Educational Research Journal. 2014. Volume 40. No. 20. P. 300-318.

${ }_{10}$ European Cluster Collaboration Platform on Education. URL: https://www.clustercollaboration.eu/tags/education 
Звертаючи увагу на порівняну синонімічність цих понять та необхідність їх уточнення, сучасний український дослідник проблем полікультурного виховання П. Кендзьор зазначає, що в сучасній системі освіти замість терміна «полікультурний» пропонують уживати термін «інтеркультурний», який означає взаємодію, обмін, перемішування й динамічніше ініціює культурну інтеракцію. Під інтеркультурністю розуміють здатність відчути на власному досвіді відмінність іншої культури й використовувати цей досвід для переосмислення власної ${ }^{11}$.

За визначенням комісії з питань освіти ЮНЕСКО, існують такі два типи освіти, як мультикультурна (полікультурна) та інтеркультурна. Мультикультурна освіта вивчає інші культури, щоб зумовлювати прийняття або хоча б толерантне ставлення до цих культур. Інтеркультурна освіта спрямована на те, щоб вийти за межі пасивного співіснування та розвиватися і співіснувати разом у мультикультурних суспільствах у взаєморозумінні, повазі та діалозі між різними культурними групами ${ }^{12}$.

Сучасні зарубіжні науковці С. Лухтенберг та С. Нієто трактують поняття «полікультурна освіта» як процес, що стосується значної різноманітності культурних партнерів, містить знання, вміння, співчуття, гнучкість, міжкультурну обізнаність, володіння іноземними мовами, які використовуються учасниками освітнього процесу ${ }^{13,14}$.

Вітчизняні дослідники проблем полікультурної освіти, підкреслюючи ії вагомість, зазначають, що розуміння полікультурності починається з усвідомлення різноманітності навколишнього світу, усвідомлення того, що і країна, в якій ти живеш, і весь світ населені представниками різних етнічних i культурних груп. Школа, орієнтуючись на індивідуальні потреби тих, хто навчається, має забезпечувати таку освіту, яка б допомагала представникам різних культур не тільки існувати, але й жити разом на основі гармонійної взаємодії. Отже, полікультурна освіта має бути процесом, а не одноразовою програмою ${ }^{15}$. У процесі взаємодії культур збільшується обсяг сприйнятих цінностей i, відповідно, змінюється й сам характер

11 Кендзьор П.І. Полікультурне виховання учнів у системі діяльності загальноосвітнього навчального закладу (теорія і методика) : дис. ... докт. пед. Наук : 13.00.07. Київ, 2017. С. 62.

${ }^{12}$ UNESCO Guidelines on Intercultural Education Paris, 2006. P. 15.

13 Luchtenberg S. Multicultural Education: Challenges and Responses. Journal of Social Science Education. 2005. Volume 4, Number 1. P. 31-55.

14 Nieto Sonia, Bode Patty. Affirming Diversity: the Sociopolitical Context of Multicultural Education. Boston: Pearson Education, 2012. 480 p.

15 Абібуллаєва Г.С. Деякі аспекти полікультурної освіти. Педагогіка і психологія. 2006. № 1. С. 75-84. 
сприйняття (стає далекогляднішим, відбиває властивості об’єкта в усій його багатогранності й глибині) ${ }^{16,17}$.

Проблеми й виклики сучасності стимулюють модернізацію полікультурної освіти, адже саме високоосвічена, толерантна, духовно багата особистість будуватиме майбутне нашої країни. Тому підвищення значущості полікультурної освіти в загальній системі освіти, розширення знань про культуру, мистецтво, традиції різних народів світу сприятимуть зміцненню взаєморозуміння між країнами, культурному розмаїттю. В умовах глобалізації виконання завдань полікультурної освіти, націленої на діалог культур, пріоритетним стає створення полікультурного середовища, толерантних взаємин між націями й народами як усередині держав, так і на міжнародному рівні.

\section{2. Міжкультурна комунікація як складник полікультурного виховання}

У сучасному глобалізованому світі міжкультурна комунікація стала звичним явищем майже в усіх сферах життя. Про це свідчать численні міжнародні заходи: політичні, культурні, наукові, спортивні, а також трудова міграція, туризм, освіта за кордоном. Усе більше людей виявляють інтерес до інших народів і культур, прагнуть пізнати їх особливості, встановити контакти 3 їх представниками, вирішити проблеми та порозумітися. Саме цим викликана загальна увага до питань міжкультурної комунікації.

Міжкультурна комунікація - складний процес об'єктивної реальності, що нараховує багато компонентів і залежить від впливу низки факторів (історичних, суспільно-політичних, соціальних, економічних тощо). Причини значного інтересу до проблем міжкультурної комунікації зумовлені, насамперед, переходом людства на новий етап свого розвитку, який описується узагальнювальним поняттям «глобалізація». Сучасне суспільство розглядається як цілісний і взаємопов'язаний світ різних культур, що постійно розвивається.

Життя в суспільстві потребує від людини набуття вміння «орієнтуватися» в культурному «просторі». Для орієнтації в культурному «просторі» людина має засвоїти «систему відносин», вироблену своєю національною спільнотою. Це дозволяє їй установлювати й підтримувати контакти з іншими людьми (незалежно від віку, статі, позицій у суспільстві).

Проте для життя i професійної діяльності в сучасному полікультурному світі людині недостатньо навчитися «орієнтуватися»

16 Ковальчук Е.С. Поликультурное воспитание в современном школьном образовании России : дис. ... канд. пед. наук. Київ, 2004. 166 с.

17 Хребтова В.В. Зародження й перспективи розвитку полікультурного виховання. Вісник Запорізького національного університету. 2007. № 2. С. 229-233. 
у своєму культурному просторі. Об'єктивні причини розвитку людської цивілізації (поширення міжнародних зв'язків i розширення міжнародного співробітництва) зумовлюють потребу людей в орієнтації в культурному просторі інших національних спільнот. У процесі міжкультурної комунікації здійснюється оцінювання «системи відносин» людей в іншій культурі, а також переоцінка цінностей рідної культури.

Міжкультурна комунікація як взаємодія представників різних культур може відбуватися в таких формах: 1) як безпосередній контакт представників різних культур; 2) як опосередкована їх комунікація (наприклад через перекладача або за допомогою проміжного технічного засобу комунікації (телефон, комп'ютер тощо)); 3) через тексти на різних носіях (паперових, електронних, аудіо- та відеопристроях), завдяки яким люди вивчають особливості іншої культури.

Передання інформації в процесі міжкультурної комунікації відбувається в таких основних формах: усній, письмовій, невербальній. Найпоширенішою формою обміну інформацією між представниками різних культур є усна форма міжкультурної комунікації (розмови людей під час безпосереднього спілкування, телефонні розмови, промови, презентації, ділові переговори, дискусії тощо).

Переваги усної форми міжкультурної комунікації полягають у швидкості обміну інформацією, в наявності надійного зворотного зв'язку завдяки безпосередньому контакту, що дозволяє регулювати і коригувати процес міжкультурної комунікації (поставити запитання, вточнити повідомлення, висловити згоду або незгоду з тим, про що говориться); в простоті здійснення комунікації.

До недоліків усної форми міжкультурної комунікації належать труднощі, пов'язані з необхідністю миттєвого пошуку точних, адекватних слів, і ймовірність не знайти їх при формулюванні повідомлення; можливість пропустити в повідомленні важливі деталі; ймовірність забути частину почутої інформації; ймовірність нерозуміння сутності повідомлення в процесі його сприймання; ймовірність викривлення змісту повідомлення в процесі його передавання іншим людям.

Письмова форма міжкультурної комунікації найбільш поширена в діловій сфері (ділова кореспонденція, ділова комунікація). Переваги письмової форми міжкультурної комунікації пов'язані 3 тим, що в процесі створення письмових повідомлень $€$ час для обдумування речень, підбору адекватних слів, граматичних форм тощо; письмова інформація, зафіксована на паперовому або електронному носії, може зберігатися впродовж тривалого часу, до неї можна знову звернутися в будь-який момент, перевірити, скорегувати тощо. Повідомлення в письмовій формі характеризуються, як правило, логічністю і точністю висловлювань.

Формування полікультурної особистості вимагає ознайомлення 3 культурою народу, мова якого вивчається, постійного оновлення 
лінгвокультурної інформації в умовах безперервної комунікативної практики, адже пізнання іншого національного світобачення та іншої культури пов'язане зі збагаченням загальної картини світу, знайомством 3 іншими ієрархіями цінностей, а також зі збагаченням власної культури та усвідомленням себе представником своєї національної спільноти.

Міжкультурну комунікацію найчастіше визначають як процес взаємного зв'язку та взаємодії представників різних культур. Це специфічна суб'єкт-суб'єктна взаємодія, під час якої відбувається обмін інформацією, досвідом, уміннями й навичками носіїв різних типів культур.

Завдання міжкультурної комунікації полягає у формуванні міжкультурної компетентності, необхідних знань про різні народи та культури 3 метою уникнення міжетнічних і міжкультурних конфліктів та встановлення комфортних умов спілкування в різних сферах та життєвих ситуаціях ${ }^{18}$.

Успішна міжкультурна комунікація передбачає постійну готовність людини до сприйняття, розуміння й прийняття чужих етнічних стереотипів поведінки, народів, звичаїв, інтересів, культурних цінностей тощо.

Значна частина проблем під час спілкування 3 представниками інших культур виникає через непорозуміння причин поведінки одне одного, коли люди в певній ситуації очікують на певну поведінку, а не дочекавшись ऑіi, доходять помилкових висновків щодо культури, 3 представником якої вони спілкуються. Тому необхідно акцентувати увагу тих, хто навчається, на характерних для іншої культури стереотипах поведінки, які, 3 одного боку, допомагають індивідові орієнтуватися в ситуаціях, що не потребують відповідальних рішень, а 3 іншого - як закріплена форма упередження відіграють негативну роль, заважають об'єктивно оцінювати суперечності, які виникають під час розвитку суспільних відносин ${ }^{19}$.

Моделі комунікативної поведінки та іiі інтерпретація залежать від сформованих у носіїв культури уявлень про принципи організації мовної взаємодії. Варіативність цих уявлень, що відображає глибинні відмінності культур, у процесі міжкультурного спілкування нерідко завершується перенесенням соціокультурних (прагматичних) норм рідної мови на іноземну та, як результат, призводить до формування в носія мови негативних стереотипів про співрозмовника. Так, «чужі» характеризуються негативно, «свої» ж сприймаються позитивно, а їх недоліки пояснюються впливом зовнішніх чинників. Очевидно, що відсутність бажання розрізняти невідповідності до стереотипу можуть

\footnotetext{
${ }^{18}$ Манакін В.М. Мова і міжкультурна комунікація. Київ : ВЦ «Академія», 2012. С. 9.

19 Шавкун І.Г. Міжкультурна комунікація як складова сучасної менеджментосвіти. Культорологічний вісник Нижньої Наддніпрянщини. 2009. Вип. 23. С. 117.
} 
призвести до неправомірних узагальнень, чому значно сприяють носії тієї культури, про яку складають своє враження іноземці ${ }^{20}$.

Також слід зазначити, що в основі виникнення різних спрощених уявлень лежить властиве нам прагнення знайти пояснення явищ і вчинків, які ми спостерігаємо (явище атрибуції, або приписування). Так, у процесі міжкультурного спілкування комуніканти, керуючись звичним для себе світосприйняттям, приписують іншим характеристики на основі цінностей рідної культури, спираючись на уявлення про їх подібність.

Важливу роль у процесі міжкультурного спілкування відіграють комунікативні стратегї, вони $є$ сукупністю мовленнєвих актів ініціатора спілкування, яка визначає лінію його мовленнєвої поведінки, моделює досягнення цілей та виконання планів і прогнозує можливі реакції реципієнта на них.

Комунікативні стратегії $\epsilon$ основним засобом реалізації комунікативних інтенцій мовця, його прагматичного впливу на партнера 3 комунікації, вирішення комунікативних завдань, запобігання комунікативним невдачам у ситуації міжкультурної комунікації.

Також вербальна комунікація грунтується на знанні вербальних та невербальних правил та проявів уваги, які дозволяють вести невимушену бесіду, постійно спрямовуючи іiі необхідним чином, не виходячи при цьому за межі ввічливості. Такі правила грунтуються на використанні стійких конструкцій і кліше, що пом'якшують різкість висловлювання і роблять розмову менш прямолінійною.

Отже, полікультурне виховання та ефективне міжкультурне спілкування особистості можливе за умов набуття нею необхідних лінгвокультурологічних знань, які разом із систематизацією уявлень про наявні міжкультурні відмінності допоможуть уникати помилкових стереотипних висновків i, відповідно, обирати коректну лінію комунікативної поведінки.

Підгрунтям інтелектуального, культурного, духовного, соціального, економічного розвитку суспільства та держави є освіта. У Національній доктрині розвитку освіти в Україні зазначено, що «мета державної політики щодо розвитку освіти полягає у створенні умов для розвитку полікультурної особистості й творчої самореалізації кожного громадянина України» ${ }^{21}$.

20 Кузьменкова Ю.Б. От традиций культуры к нормам речевого поведения британцев, американцев и россиян. Москва : Изд. дом ГУ ВШЭ, 2005. С. 102.

${ }^{21}$ Про Національну доктрину розвитку освіти : Указ Президента України від 17.04.2002 № 347. 2002. 14 c. 


\section{3. Стратегія державної політики щодо полікультурної освіти}

Інтеграція національної освіти в загальноєвропейську систему здійснюється 3 урахуванням таких основних принципів державної освітньої політики в Україні, як пріоритетність освіти, ії демократизація, гуманізація та гуманітаризація, національна спрямованість, безперервність, багатокультурність і варіативність освіти, відкритість системи освіти та нероздільність навчання і виховання.

Необхідність розвитку національної системи полікультурної освіти викликана проголошенням ООН та ЮНЕСКО нової культурної та освітньої політики, яка грунтується на ідеї підтримки людської гідності на базі загальнолюдських цінностей. Міжнародна комісія 3 освіти ЮНЕСКО у своїй доповіді на форумі наголосила, що виховання й навчання повинні сприяти тому, щоб, з одного боку, людина усвідомила свої корені і тим самим могла визначити місце, яке вона посідає в сучасному світі, а з іншого - виховати в ній повагу до інших культур. Цей документ особливо акцентує увагу на тому, що молодь, освоюючи культурну спадщину свого народу, повинна 3 повагою ставитися до культурних цінностей представників інших національностей ${ }^{22}$.

Питання діалогу культур $є$ важливим та актуальним для нашої країни, адже Україна $є$ багатонаціональною державою, має власний унікальний територіальний устрій (на межі європейської та азійської цивілізацій) та свої етнічні, культурні, а також соціально-економічні особливості.

В українському законодавстві закладено основи полікультурного виховання, ідея полікультурності відображена в багатьох національних державних документах. Аналізуючи нормативно-правове забезпечення полікультурного виховання в Україні, вітчизняний науковець П. Кендзьор зазначає, що попри значний інтерес учених із різних галузей знань, проблема полікультурного виховання поки не набула цілісного наукового осмислення, досі не складено цілісної системної характеристики процесу організації полікультурного виховання в особистісному й соціальному вимірах ${ }^{23}$. Адже сьогодні в Україні ще не розроблено національної концепції розвитку полікультурного виховання, незважаючи на актуальність проблеми.

Зміст та особливості реалізації полікультурного виховання в Україні визначаються Конституцією України, Національною доктриною розвитку освіти, Державною національною програмою «Освіта»

${ }^{22}$ Hernes G., Martin M., Zadra E. Planning for diversity: education in multi-ethnic and multicultural societies. International Institute for Education Planning Policy Forum (Paris, 19-20 June 2003). Paris, 2004. 376 p.

23 Кендзьор П.І. Полікультурне виховання учнів у системі діяльності загальноосвітнього навчального закладу (теорія і методика) : дис. ... докт. пед. наук : 13.00.07. Київ, 2017. С. 8. 
(Україна XXI століття), «Концепцією національно-патріотичного виховання», Державними стандартами освіти, наказами й рекомендаціями Міністерства освіти і науки України.

На визначення інтеркультурного виховання «як навчання різноманітності культур, виховання поваги та почуття гідності в представників усіх культур, незважаючи на расове або етнічне походження, сприйняття взаємозв'язку та взаємовпливу загальнолюдського та національного компонентів культури в широкому значенні», натрапляємо в проекті «Концепції громадянського виховання особистості в умовах розвитку української державності» $(2000)^{24}$. Зазначається, що принцип інтеркультурності, який передбачає інтегрованість української національної культури в контекст загальнодержавних, європейських і світових цінностей, у загальнолюдську культуру, $€$ одним із найважливіших серед підходів та принципів виховання громадянина, адже зберегти свою національну ідентичність може лише особистість, яка «усвідомлює національну культуру як невід'ємний складник культури світової» ${ }^{25}$. Одним із завдань громадянського виховання та освіти автори проекту називають «формування інтеркультурного менталітету, можливість сприйняття культурного плюралізму, загальнолюдських цінностей, толерантного ставлення до інших культур і традицій» ${ }^{26}$.

«Національна доктрина розвитку освіти» (2002) пріоритетними напрямами державної політики щодо розвитку освіти проголошує формування національних і загальнолюдських цінностей, створення для всіх громадян України рівних можливостей у здобутті освіти, забезпечення освітніх потреб національних меншин, інтеграцію вітчизняної освіти в європейський i світовий освітній простір. Зазначається, що «мета державної політики щодо розвитку освіти полягає у створенні умов для розвитку особистості i творчої самореалізації кожного громадянина України» ${ }^{27}$, важливим $\epsilon$ «формування в молоді сучасного світогляду, розвиток творчих здібностей і навичок самостійного наукового пізнання, самоосвіти і самореалізації особистості». Крім того, підкреслюється, що «передумовою утвердження розвинутого громадянського суспільства $€$ підготовка освічених, моральних, мобільних, конструктивних

${ }^{24}$ Проект Концепції громадянського виховання особистості в умовах розвитку української державності. Педагогічна газета. 2000. № 6 (72). С. 4.

${ }^{25}$ Проект Концепції громадянського виховання особистості в умовах розвитку української державності. Педагогічна газета. 2000. № 6 (72). С. 4.

${ }^{26}$ Проект Концепції громадянського виховання особистості в умовах розвитку української державності. Педагогічна газета. 2000. № 6 (72). С. 4.

27 Про Національну доктрину розвитку освіти : Указ Президента України від 17.04.2002 р. № 347/2002. С. 2. 
і практичних людей, здатних до співпраці, міжкультурної взаємодії...» ${ }^{28}$. Також у документі зазначено, що «освіта реалізує право національних меншин на задоволення освітніх потреб рідною мовою, збереження й розвиток етнокультури, iї підтримку й державний захист. У навчальних закладах із мовами національних меншин створюються умови для належного опанування державної мови та багатокультурної освіти» ${ }^{29}$.

Сьогодні в Україні значну увагу приділяють полікультурності як принципу державної політики загалом й освітньої зокрема. На державному рівні забезпечуються права і свободи всіх етнічних груп на культурне самовираження та розвиток. Реалізація цих прав і свобод вимагає від усіх народів й етносів, які проживають в Україні, взаємного толерантного ставлення. Така державна й освітня політика відповідає європейським підходам до налагодження міжкультурної комунікації й досягнення взаєморозуміння між представниками різних етнічних груп і культурних традицій у спільноті.

Принцип полікультурної спрямованості навчально-виховного процесу передбачає, що полікультурне виховання в закладах освіти має сприяти створенню комфортного гуманістичного соціального клімату, який сприятиме гармонізації відносин між представниками різних соціокультурних груп. Також слід створювати умови для формування позитивного сприйняття тими, хто навчається, інших культур, націй, релігій та виховувати в них толерантне ставлення та здатність об'єктивно оцінювати події в контексті «діалогу культур». Адже цілями полікультурної освіти й виховання $є$ формування всебічно розвиненої особистості, здатної до творчого саморозвитку, на основі національної та світової культурних спадщин та традицій; розширення можливостей іiі самореалізації; виховання розуміння самобутності культур різних народів, дбайливого ставлення до національних цінностей.

Реалізація полікультурного компонента може здійснюватися через збагачення освітніх дисциплін полікультурною проблематикою шляхом включення в навчальний процес додаткових матеріалів, що сприяють полікультурній освіті тих, хто навчається.

«Концепція національно-патріотичного виховання» проголошує, що «на сучасному етапі становлення української державності побудова нового громадянського суспільства та його інтеграція в європейське і світове співтовариство $є$ пріоритетними завданнями України. Становлення українського народу як єдиної політичної нації має стати об'єднувальною ідеєю формування сучасної

28 Про Національну доктрину розвитку освіти : Указ Президента України від 17.04.2002 p. № 347/2002. С. 3.

${ }^{29}$ Про Національну доктрину розвитку освіти : Указ Президента України від 17.04.2002 p. № 347/2002. C. 4. 
багатонаціональної полікультурної держави, в якій тісно переплетені культури багатьох народів, їх мови, традиції та звичаї» ${ }^{30}$. Також передбачено, що «національне виховання <...> однаково стосується й українців, і представників інших народів, що проживають в Україні». Підкреслено, що «життєві реалії сьогодення акцентують увагу на принципах рівноправного співіснування різних форм культурного життя національних меншин України, на загальнолюдських цінностях, що виховують у суспільстві толерантність, повагу до інших поглядів, культур, релігій, уміння спілкуватися й адаптуватися в полікультурному середовищі» ${ }^{31}$. Саме тому сьогодні особливо важливими $€$ питання надання рівних можливостей представникам усіх етносів для пізнання своєї історії, традицій, мови, культури, формування власної національної гідності. Адже пізнання власної історико-культурної спадщини допоможе пізнати глибинність взаємозв'язків кожного з них 3 українською нацією. Ті, хто навчаються, мають усвідомити спільність інтересів усіх етносів українського народу в розбудові України, формування міжнаціональної толерантності.

Отже, особливу увагу слід звернути на те, як збагачується кожна людина внаслідок взаємодії з представниками інших культур, що саме допомагає людям співіснувати у світовому просторі. Поважаючи та вивчаючи культуру інших народів, ми зростаємо духовно. Результатом полікультурної освіти є виховання громадянина, який відчуває себе не тільки представником певної культури, але й громадянином світу, який сприймає себе суб'єктом діалогу культур, усвідомлює свою роль та відповідальність у глобальних загальнолюдських процесах.

Демократія та євроінтеграційні прагнення України потребують вирішення мовних питань та впровадження толерантних і правових методик подолання мовних конфліктів. Важливу роль у реалізації принципу полікультурності відіграє державна мовна політика України. Концепція державної мовної політики є системою основоположних нормативних настанов, які грунтуються на комплексній оцінці мовної ситуації в Україні та якими мають керуватися органи державної влади та органи місцевого самоврядування у своїй практичній діяльності при регулюванні суспільних відносин у мовній сфері. Реалізація Концепції закріплена статтею 10 Конституції України, яка встановлює, що «держава сприяє вивченню мов міжнародного спілкування.

30 Концепція національно-патріотичного виховання : наказ МОН № 641 від 16.06.2015 p.

31 Концепція національно-патріотичного виховання : наказ МОН № 641 від 16.06.2015 p. 
Застосування мов в Україні гарантується Конституцією України та визначається законом» ${ }^{32}$.

Таким чином, розвиток багатокультурного суспільства не $\epsilon$ можливим без урахування цінностей кожної етнічної групи, що передбачає принцип полікультурності у всіх його проявах, зокрема в галузі освіти, адже освіта формує світогляд та впливає на систему цінностей людини, відтворює моральні й загальнокультурні пріоритети народу й держави, закладає підвалини розвитку суспільства.

\section{ВИСНОВКИ}

Таким чином, сьогодні в Україні значну увагу приділяють полікультурності як принципу державної політики загалом й освітньої зокрема. Сучасні університети покликані готувати фахівців, здатних жити й успішно функціонувати в умовах полікультурного суспільства. Тому зміст вищої освіти має відповідати вимогам глобального ринку праці. Університети та діяльність викладачів відображають цінності культури, в якій вони перебувають.

Головною метою вищої освіти $є$ створення умов для особистісного розвитку i творчої самореалізації кожного громадянина України, збереження та розвиток цінностей національної культури, а також забезпечення на державному рівні прав i свобод на культурне самовираження. Для зміцнення демократії освітні системи повинні враховувати багатокультурний характер суспільства й прагнути активно сприяти мирному співіснуванню і позитивній взаємодії між різними культурними групами.

Одним із головних способів організації полікультурного виховання $\epsilon$ забезпечення культурологічної спрямованості освіти та введення полікультурного компонента в різні навчальні дисципліни.

Навчання міжкультурного спілкування передбачає одночасне вивчення мови й культури, а також вивчення комунікативних стратегій як одиниць, що одночасно належать мові та культурі, мають соціальну та національно-культурну специфіку. Успішна міжкультурна комунікація передбачає постійну готовність людини до сприйняття, розуміння й прийняття чужих етнічних стереотипів поведінки, культурних цінностей тощо.

Сучасні умови розвитку суспільства, демократичні перетворення, економічні та наукові реформи, зміни в гуманітарних напрямах зумовлюють необхідність посилення ролі полікультурної освіти як динамічної системи, яка безпосередньо впливає на розвиток високоосвіченої, творчої, національно свідомої особистості.

${ }^{32}$ Конституція України: за станом на 8 грудня 2004 р. Верховна Рада України. Київ : Видавничий дім «Скіф», 2009. С. 12. 
Полікультурне виховання є невід'ємним складником виховання громадянина, адже охоплює вивчення різноманітних культур, виховання поваги до представників усіх культур, незважаючи на расове, етнічне походження, сприйняття взаємозв'язку та взаємовпливу загальнолюдського й національного компонентів культури в широкому значенні.

\section{АНОТАЦІЯ}

У статті 3'ясовується питання про зародження й перспективи розвитку полікультурного виховання, аналізується стан названої проблеми в сучасній педагогіці, характеризується загальнопедагогічне питання сутності полікультурного виховання, визначається специфіка та основні етапи розвитку полікультурного виховання відповідно до нової освітньої парадигми. Поліпшення якості та практичного спрямування освіти $є$ інструментом, що забезпечує всебічний розвиток кожної особистості, активну участь у професійному, соціальному, культурному житті суспільства, ефективне спілкування з представниками інших культур на основі поваги, усвідомлення цінностей та неповторності розмаїття народів, створює передумови для інтегрування у світове співтовариство. Автори статті розглядають виховання полікультурної особистості в процесі міжкультурної комунікації, яка визначається як процес взаємного зв'язку та взаємодії представників різних культур. Наголошується, що полікультурне виховання та ефективне міжкультурне спілкування особистості можливе за умов набуття нею необхідних лінгвокультурологічних знань. Питання полікультурної освіти молоді в Україні досліджуються з урахуванням державної політики та педагогічної стратегії. Значна увага приділяється вивченню фундаментальних державних документів. Зроблено акцент на визначенні ролі державної та освітньої політики при формуванні полікультурної вихованості студентської молоді України.

\section{ЛIТЕРАТУРА}

1. Абібуллаєва Г.С. Деякі аспекти полікультурної освіти. Педагогіка і психологія. 2006. № 1. С. 75-84.

2. Выготский Л.С. Избранные психологические исследования. Москва, 1956. 520 с.

3. Каптерев П.Ф. Избранные педагогические сочинения. Москва, 1982. $421 \mathrm{c}$.

4. Кендзьор П.І. Полікультурне виховання учнів у системі діяльності загальноосвітнього навчального закладу (теорія і методика) : дис. ... докт. пед. наук : 13.00.07. Київ, 2017. 504 с. 
5. Ковальчук Е.С. Поликультурное воспитание в современном школьном образовании России: дис. ... канд. пед. наук : 13.00.01. Київ, 2004. $166 \mathrm{c}$.

6. Коменский Я.А. Избранные педагогические сочинения: В 2 т. Т. 2. Москва : Педагогика, 1982. 576 с.

7. Конституція України: за станом на 8 грудня 2004 р. Верховна Рада України. Київ : Видавничий дім «Скіф», 2009. 48 с.

8. Концепція національно-патріотичного виховання : Наказ МОН № 641 від 16.06.2015 p.

9. Кузьменкова Ю.Б. От традиций культуры к нормам речевого поведения британцев, американцев и россиян. Москва : Изд. дом ГУ ВШЭ, 2005. 316 с.

10. Манакін В.М. Мова і міжкультурна комунікація. Київ : ВЦ «Академія», 2012. 288 с.

11. Проект Концепції громадянського виховання особистості в умовах розвитку української державності. Педагогічна газета. 2000. № 6 (72). C. 4-6.

12. Про Національну доктрину розвитку освіти : Указ Президента України від 17.04.2002 № 347/2002. 14 с.

13. Хребтова В.В. Зародження й перспективи розвитку полікультурного виховання. Вісник Запорізького національного університету. 2007. № 2. С. 229-233.

14. Шавкун І.Г. Міжкультурна комунікація як складова сучасної менеджмент-освіти. Культорологічний вісник Нижньой Наддніпрянщини. 2009. Вип. 23. С. 115-118.

15. Banks J. A. Multicultural Education: Characteristics and Goals. Multicultural Education: Issues and Perspectives. 7th edition. John Wiley and Sons, 2010. 480 p. P. 3-30.

16. European Cluster Collaboration Platform on Education. https://www.clustercollaboration.eu/tags/education.

17. Faas D., Hajisoteriou C., Angelides P. Intercultural education in Europe: Policies, practices and trends. British Educational Research Journal. 2014. Volume 40. No. 20. P. 300-318.

18. Hernes G., Martin M., Zadra E. Planning for diversity: education in multi-ethnic and multicultural societies. International Institute for Education Planning Policy Forum (Paris, 19-20 June 2003). Paris, 2004. 376 p.

19. Hunter William A. Multicultural Education Through CompetencyBased Teacher Education. Washington, D.C. : American Association for Colleges of Teacher Education, 1974. 276 p.

20. International Dictionary of Education by G. Terry Page \& J. B. Thomas ; with A. R. Marshall. The MIT Press, 1980. 224 p.

21. International Encyclopedia of Education. Vol. 7. Oxford : Rergamon Press, 1994. P. 40-64. 
22. Luchtenberg S. Multicultural Education: Challenges and Responses. Journal of Social Science Education. 2005. Volume 4, Number 1. P. 31-55.

23. Nieto Sonia, Bode Patty. Affirming Diversity: the Sociopolitical Context of Multicultural Education. Boston: Pearson Education, 2012. 480 p.

24. UNESCO Guidelines on Intercultural Education Paris, 2006. 43 p.

\section{Information about the authors:}

Vertehel V. L.,

Ph.D. in Pedagogic Sciences, Associate Professor, Associate Professor at the Department of Foreign Languages for Specific Purposes Zaporizhzhia National University 66, Zhukovskoho str., Zaporizhzhia, 69600, Ukraine

\section{Khrebtova V. V.,}

Ph.D. in Pedagogic Sciences, Associate Professor, Associate Professor at the Department of Foreign Languages for Specific Purposes Zaporizhzhia National University 66, Zhukovskoho str., Zaporizhzhia, 69600, Ukraine 